Visions of Electric Media 


\section{Televisual Culture}

Televisual culture encompasses and crosses all aspects of television - past, current and future - from its experiential dimensions to its aesthetic strategies, from its technological developments to its crossmedial extensions. The 'televisual' names a condition of transformation that is altering the coordinates through which we understand, theorize, intervene, and challenge contemporary media culture. Shifts in production practices, consumption circuits, technologies of distribution and access, and the aesthetic qualities of televisual texts foreground the dynamic place of television in the contemporary media landscape. They demand that we revisit concepts such as liveness, media event, audiences and broadcasting, but also that we theorize new concepts to meet the rapidly changing conditions of the televisual. The series aims at seriously analyzing both the contemporary specificity of the televisual and the challenges uncovered by new developments in technology and theory in an age in which digitization and convergence are redrawing the boundaries of media.

Series editors

Sudeep Dasgupta, Joke Hermes, Misha Kavka, Jaap Kooijman, Markus Stauff 


\section{Visions of Electric Media}

Television in the Victorian and Machine Ages

Ivy Roberts 
Cover illustration: 'Professor Goaheadison's Latest,' Fun, 3 July 1889, 6.

Cover design: Coördesign, Leiden

Lay-out: Crius Group, Hulshout

ISBN $\quad 9789462986596$

e-ISBN $\quad 9789048537877$

DOI $\quad 10.5117 / 9789462986596$

NUR $\quad 670$

(C) I. Roberts / Amsterdam University Press B.V., Amsterdam 2019

All rights reserved. Without limiting the rights under copyright reserved above, no part of this book may be reproduced, stored in or introduced into a retrieval system, or transmitted, in any form or by any means (electronic, mechanical, photocopying, recording or otherwise) without the written permission of both the copyright owner and the author of the book.

Every effort has been made to obtain permission to use all copyrighted illustrations reproduced in this book. Nonetheless, whosoever believes to have rights to this material is advised to contact the publisher. 